\title{
A Rare Cause of Acute Hepatitis: Salmonella Sepsis Due to Uncooked Egg
}

\section{Nadir Bir Akut Hepatit Nedeni: Çiğ Yumurta Kaynaklı Salmonella Sepsisi}

\author{
Ezgi Bayrakdaroğlu' ${ }^{1}$ Şeyma Karatekin² ${ }^{2}$ Illknur Kurt ${ }^{1}$, Rengin Şiraneci ${ }^{3}$, Tarık Yıldırım³ ${ }^{3}$ Kazım Okan Dolu ${ }^{1}$ \\ ${ }^{1}$ Clinic of Pediatrics, Istanbul Health Sciences University, Kanuni Sultan Suleyman Training and Research Hospital, Istanbul, Turkey \\ 2 Deparment of Pediatrics, Erzincan University School of Medicine, Erzincan, Turkey \\ ${ }^{3}$ Clinic of Pediatric Infectious Diseases, Istanbul Health Sciences University, Kanuni Sultan Suleyman Training and Research Hospital, Istanbul, Turkey
}

Cite this article as: Bayrakdaroğlu E, Karatekin Ş, Kurt i, Şiraneci R, Yıldıım T, Dolu KO. A rare cause of acute hepatitis: salmonella sepsis due to uncooked egg. J Pediatr Inf 2019;13(2):e80-e82

\section{Abstract}

In this case report, an eigth months girl patient who recieved treatment with the diagnosis acute hepatitis in our hospital's pediatric infection clinic and who had Salmonella spp. in blood culture is mentioned. Food intake was questioned for a patient who presented with acute hepatitis and had normal viral serology. We learn that mother eated her baby with raw egg. The transmission pathways and clinical manifestations of Salmonella spp., which are still important disease factors and therefore public health problems in developing countries, were studied.

Keywords: Hepatitis, uncooked egg, sepsis, salmonella infections öz

Bu olgu sunumunda, hastanemiz çocuk enfeksiyon kliniğinde akut hepatit tanısıyla takip edilen ve kan kültüründe Salmonella spp. üreyen 8 aylık kız hastadan bahsedildi. Akut hepatit tablosu ile başvuran ve viral serolojisi normal olan bir hastada ek gıda alımı sorgulandığında, çiğ yumurta yeme öyküsünün olması vurgulanmak istendi. Gelişmekte olan ülkelerde hala önemli birer hastalık etkeni ve dolayısıyla halk sağlığı problemi olan Salmonella türlerinin bulaş yolları ve yol açtıkları klinik tablolar incelendi.

Anahtar Kelimeler: Hepatit, çiğ yumurta, sepsis, salmonella enfeksiyonu

Correspondence Address / Yazışma Adresi

Ezgi Bayrakdaroğlu

İstanbul Sağlık Bilimleri Üniversitesi,

Kanuni Sultan Süleyman Eğitim ve Araştırma Hastanesi,

Çocuk Sağlığı ve Hastalıkları Kliniği,

İstanbul-Türkiye

E-mail: ezgibayrakdaroglu@hotmail.com 


\section{Introduction}

Salmonellas are gram-negative rods belonging to Enterobacteriaceae family and have 11 serogroups. More than two thousand Salmonella serotypes are known, and most of these are classified in $O$ serogroup $(1,2)$. In recent years, the incidence of typhoid fever has decreased but the incidence of salmonella enteritis has increased (3). Salmonella infections in people who are mostly infected due to contaminated food and water consumption may present as enteric fever, acute gastroenteritis, acute hepatitis, local infection and bacteraemia. As a result of consumption of contaminated food and water by humans, salmonella infections appear as epidemics and constitute a public health problem in this context. Chicken meat and eggs are the most common foods that cause salmonella infections (3).

\section{Case Report}

An 8-month-old female patient was brought to our hospital for fever, vomiting, diarrhea, loss of appetite and fatigue for two days. In the patient's medical history, it was determined that she applied to the another centre once during this period and she was prescribed analgesic-antipyretic (paracetamol, ibufrofen) with oral amoxicillin/clavulonate anti-biotherapy by providing intravenous fluid support. Because her complaints continued, she consulted to us and we saw that she had a history of developmental dysplasia of the hip. In his family history, it was learned that her patient had a $1^{\text {st }}$ degree relative marriage and his father had hepatitis in his childhood without any etiology and he received treatment for brucella infection.

According to the laboratory analysis: hemoglobin was 10 $\mathrm{g} / \mathrm{dL}$, leukocyte was $11.900 / \mathrm{mm}^{3}$, neutrophil was $6000 / \mathrm{mm}^{3}$, and platelet was 251 thousand/uL. Biochemical parameters indicated that sodium was $133 \mathrm{mmol} / \mathrm{L}$, potassium was 3.8 $\mathrm{mmol} / \mathrm{L}$, chlorine was $100 \mathrm{mmol} / \mathrm{L}$, urea was $20 \mathrm{mg} / \mathrm{dL}$, and creatinin was $0.3 \mathrm{mg} / \mathrm{dL}$. The patient's C-reactive protein (CRP) value was $61 \mathrm{mg} / \mathrm{L}$. When the liver function tests were examined, the patient had very high values of alanine aminotransferase (ALT) of $1936 \mathrm{U} / \mathrm{L}$, aspartate aminotransferase (AST) of $1620 \mathrm{U} / \mathrm{L}$, lactate dehydrogenase (LDH) of $1079 \mathrm{U} / \mathrm{L}$, and she had blood albumin value of $3.5 \mathrm{~g} / \mathrm{dL}$ and total/direct bilirubin value of $0.36 / 0.18 \mathrm{mg} / \mathrm{dL}$ in normal limits. While the ammonia value was in the normal range of $47 \mathrm{ug} / \mathrm{dL}$, the coagulation parameters resulted in activation of partial thromboplastic time of $38 \mathrm{~s}$, prothrombin time of $19.5 \mathrm{~s}$, and INR of 1.61. The patient was hospitalized in paediatric infectious service of our hospital with the diagnosis of acute hepatitis.

Blood and stool cultures were studied. Viral serology (HBsAg, anti-Hbs, anti-HbclgM, antiHAV, anti-HCV, anti-HIV), brucella and salmonella tube agglutination were studied. At the time of her admission, she was weak and her CRP value was $61 \mathrm{mg} / \mathrm{L}$ and then, she was started to $150 \mathrm{mg} / \mathrm{kg} /$ day cefotaxime anti-biotherapy. Intravenous vitamin $\mathrm{K}$ was administered to the patient whose coagulation parameters were affected. $\mathrm{N}$-acetyl cysteine infusion was started with the suggestion of paediatric gastroenterology to the patient whose transaminase values were high. There was no intra-abdominal pathology in the abdominal ultrasonography (USG). The patient's physical examination and laboratory findings gradually improved with the current treatments.

Entamoeba histolytica antigen of the patient whose amoebic cysts were detected in the stool microscopy conducted at another centre was negative. There was no reproduction in stool culture. The patient's brucella tube agglutination test was negative, and salmonella tube agglutination (GruberWidal test) was positive at 1/320 titre. In blood culture, Salmonella spp. reproduced. When the family was re-interrogated and the history was deepened, it was learned that the 8-month-old female patient was fed with raw quail eggs by her family. It was determined that our patient was contaminated with the Salmonella agent orally from quail eggs. The patient was admitted to our clinic with acute hepatitis secondary to the causative agent. She was hospitalized and treated and discharged with full recovery.

\section{Discussion}

As a result of consumption of contaminated food and water by humans, salmonella infections appear as epidemics and constitute a public health problem in this context. The most common foods that cause Salmonella infections are contaminated chicken meat and eggs (4). Even in areas where salmonellosis is common, acute hepatitis table secondary to the agent is rare (5). As in our patient, early diagnosis of cases with nonspecific clinical findings may be difficult.

The salmonellosis clinic presents high fever, abdominal pain, diarrhoea and vomiting. In the laboratory, high levels of transaminases may be detected and physical examination can reveal hepatosplenomegaly. In this sense, it can be confused with clinical acute viral hepatitis and the diagnosis becomes difficult. Fever is high in viral hepatitis cases in prodromal period but decreases before the onset of icteric phase. Especially in endemic areas, salmonellosis should be considered in cae of high fever clinic with icterus and transaminase elevation (6). In our case, the viral serology was found to be negative and Gruber Widal tube agglutination was found to be positive at $1 / 320$ titer. In addition to the Gruber Widal tube agglutination test, polymerase chain reaction (PCR), liver biopsy, blood and stool cultures can be used to reach final diagnosis (2-6). In our patient, the agent Salmonella reproduced in blood culture.

In more than $50 \%$ of salmonellosis cases, transaminases are known to be elevated from low to peak. Icterus is seen in 
less than $10 \%$ of cases. We did not have icterus in our patient and her bilirubin values were determined in normal limits. Serum albumin levels were found to be normal in terms of liver reserve evaluation and coagulation parameters were affected. ALT/AST values were found to exceed $1000 \mathrm{U} / \mathrm{L}$. Because of the normal ammonia value, Reye Syndrome was excluded in the differential diagnosis. Some patients may not have hepatomegaly. In our patient, no physical examination revealed hepatomegaly. In regions where salmonellosis is endemic as our country, salomonellosis should be considered in the diagnosis in cases with negative viral serology and unexplained transaminase elevation. It is suggested that ALT/LDH ratio is effective in differentiating salmonella hepatitis from acute viral hepatitis. This rate is lower than 4 in Salmonella hepatitis, but higher than 5 in acute viral hepatitis. In our patient, the ratio of ALT/LDH (1936/1079) was found to be 1.79; that was less than 4 (7).

The presented case is also a case of salmonella septicaemia. Salmonella spp. are rapidly formed, mixing from the intestine into the bloodstream, spreading through the blood and settling in various organs. Antibiotic therapy in uncomplicated salmonella gastroenteritis increases the risk of carriage, whereas in children under 3 months, antibiotic treatment should be applied in patients with primary or secondary immunodeficiency, in malignant individuals with the presence of severe colitis, chronic gastrointestinal disease, hemoglobinopathy and in patients having salmonella reproduction in the blood culture (2). Patients who have salmonella reproduction in their blood culture may die if they are not treated. We also applied intravenous cefotaxime treatment to our patient. Salmonella can be isolated from the blood, especially in the first week of the disease, but less in the second week. It is also found in bone marrow when it is produced from blood. Salmonella specy most commonly produced in blood cultures is Salmonella typhimurium (8). Chloramphenicol, ampicillin and trimethoprim-sulfamethoxazole are primarily preferred drugs in the treatment of salmonellosis. After the development of resistance to these agents in varying proportions is determined in the Salmonella spp., one of the third generation cephalosporins such as cefoperazone, cefotaxime and ceftriaxone in children and quinolone derivatives in adult patients may be preferred in empirical treatment. In recent years, resistance development to quinolones and broad-spectrum cephalosporins has been reported. The use of correct and rational antibiotics gains importance at this point. Azithromycin is another antibacterial agent that can be applied in cases with persistent typhoidal fever or nontyphoidal salmonellosis $(9,10)$. Treatment should be continued for 7-10 days in bacte- raemia and can be extended to 14 days, if necessary (2). For localized infections such as osteomyelitis and meningitis, the treatment should be continued for 4-6 weeks. In our country,

\section{Conclusion}

all salmonella cases detected by the laboratory are required to be notified.

In conclusion, in our case, salmonella hepatitis was diagnosed as a result of the reproduction of the agent in the blood culture while investigating the causes that may lead to acute hepatitis. Salmonellosis, which may present with different clinical manifestations, should not be forgotten in differential diagnosis especially in non-icteric acute hepatitis picture where fever persists. While presenting this case, we have wanted to emphasize that the families should be warned again and again about the risks of raw quail eggs consuming behaviour which is getting more and more common among mother.

Informed Consent: Informed consent was obtained.

Peer-review: Externally peer-reviewed.

Author Contributions: Consept - EB, ŞK, İK; Design - EB, ŞK; Supervision - RŞ, TY; References - EB, ŞK, IK, KOD; Data Collection and/ or Interpretation - EB, IK, KOD; Analysis - EB, ŞK; Literature Search - EB; Writing - EB; Critical Review - ŞK, RŞ.

Conflict of Interest: The authors have not reported a conflict of interest.

Financial Disclosure: There is no financial support in this study.

\section{References}

1. Küçüker MA, Tümbay E, Anğ Ö. Tibbi Mikrobiyoloji. Istanbul: Nobel Tıp Kitabevi, 1997:202-4.

2. Kimberlin DW, Brady MT, Jackson MA, Long SS. Red Book. Chicago: AAP Publications, 2015:737-40.

3. Salmonella Enfeksiyonlarının Mikrobiyolojik Tanııı. T.C. Sağlık Bakanlığı Ulusal Mikrobiyoloji Standartları, 2015;5.

4. Karakeçili F, Çıkman A, Karagöz A. Bir düğün yemeği sırasında gıda kaynaklı Salmonella typhimurium salgını. Klimik Dergisi 2017;30:131-5.

5. Arabacı F, Irmak H, Akdeniz H, Demiröz AP. Kolestazla seyreden bir sarılık olgusu nedeniyle: Tifo hepatiti. Infeksiyon Dergisi 2003;17:99-102.

6. Vatansev C, Gölcük M, Yılmaz H, Pamukçu A. Salmonella hepatiti: tıkanma sarılığı ile karışan iki olgu. Genel Tıp Dergisi 2003;13:131-4.

7. Uygun A, Polat Z. Viral hepatit dışı serum transaminaz düzeyinde artışa neden olan hastalıklar. Güncel Gastroenteroloji 2009;13:211-24.

8. Balcı I, Alkan GN, Bayram A. Kan kültürlerinde salmonella sıklığı ve antibiyotik duyarlılıkları. Van Tıp Dergisi 1999;4:25-7.

9. Angelo KM, Reynolds J, Karp BE, Hoekstra RM, Scheel CM, Friedman C. Antimicrobial resistance among nontyphoidal salmonella isolated from blood in the United States. J Infect Dis 2016;214:10:1565-70.

10. Nelson JD. Nelson's pediatric antimicrobial therapy. Chicago: $A A P$ Publications, 2015:86. 